\title{
Financiamiento destinado a los emprendedores argentinos
}

Finance Earmarked for Argentinian Entrepreneurs

Financiamento destinado aos empreendedores argentinos

Leandro Hernán García De Brahi

Facultad de Ciencias Económicas, Universidad

Nacional del Litoral, Argentina.

E-mail: Igarciadebrahi@gmail.com

\section{Resumen}

Dada la importancia que tiene el emprendedurismo no solo para el emprendedor sino también para el desarrollo de un país como Argentina, se consideró relevante conocer cuál era su situación en Argentina y de qué forma desde las instituciones públicas y privadas se promovía su crecimiento y fortalecimiento, a través del otorgamiento de instrumentos financieros. Para ello se realizó un trabajo de investigación, en donde en una primera etapa se indagó sobre las generalidades de los emprendedores y del ecosistema emprendedor, tecnología del financiamiento, las fuentes de financiamiento, etapas al momento de percibir el financiamiento. Luego, se identificó la actividad emprendedora en Argentina, y su posición en el ranking latinoamericano en virtud del Índice de Condiciones Sistémicas para el Emprendimiento Dinámico que elabora el Programa de Desarrollo Emprendedor que se enmarca en el Instituto de Industria de la Universidad Nacional de General Sarmiento (UNGS). Adicionalmente, se hizo un relevamiento de la estadística disponible de instrumentos financieros aprobados destinados a emprendedores. Dentro de estos se identificaron 198 instrumentos financieros ofrecidos por los organismos públicos en los distintos estamentos de la región Santa Fe, Córdoba y Buenos Aires, así como organizaciones privadas nacionales e internacionales. El 53,54 \% de los instrumentos

Palabras clave

- Financiamiento

- Emprendedor

- Emprendedurismo

- Instrumentos financieros

- Beneficios promocionales corresponden a premios, el $17,17 \%$ son Aportes No Reembolsables y el $18,69 \%$ son Créditos. A su vez, se efectuaron entrevistas a informantes clave (consultores, evaluadores, gerentes de entidades financieras) con la finalidad de detectar los inconvenientes que afrontan los emprendedores para acceder a fondos que los ayudan a desarrollar su emprendimiento. 
Keywords

- Finance

- Entrepreneur

- Entrepreneurship

- Financial instruments

- Promotional benefits

\begin{abstract}
Since entrepreneurship is relevant not only for entrepreneurs but also for the development of countries such as Argentina, it has become interesting to find out about its current situation in Argentina and about how public and private institutions foster its growth and strengthening by providing financial instruments. In order to gather that information, a research was carried out. Its first stage consisted in looking into entrepreneurs and their situation in general, into financing technology, the sources of finance and the steps followed when finance is received. Then, the activity of entrepreneurs in Argentina was identified and positioned in the Latin American ranking according to the Systemic Conditions for Dynamic Entrepreneurship Rates designed by the Program of Entrepreneurial Development which belongs to Instituto de Industria from Universidad Nacional de General Sarmiento (UNGS). Furthermore, a review of available statistics of approved financial instruments earmarked for entrepreneurs was conducted. Among them, 198 financial instruments offered by public organizations at different levels of the region made up of Santa Fe, Córdoba and Buenos Aires, as well as national and international private organizations. $53.54 \%$ of the instruments are prizes, $17.17 \%$ are non-refundable contributions and $18.69 \%$ are credits. Besides, interviews with key informants (advisers, evaluators, financial entities' managers) were carried out. They aimed at identifying the problems entrepreneurs face to get funding in order to carry out their activities.
\end{abstract}

\section{Resumo}

Pela importância que tem 0 empreendedorismo, não só para 0 empreendedor mas também para o desenvolvimento de um país como Argentina, considerou-se relevante conhecer qual era a sua situação na Argentina e de que forma desde as instituições públicas e privadas promovia-se seu crescimento e fortalecimento, através da outorga de instrumentos financeiros. Para isso realizou-se um trabalho de pesquisa, no que numa primeira etapa, indagou-se sobre as generalidades dos empreendedores e do ecossistema empreendedor, tecnologia do financiamento, as fontes de financiamento, etapas ao momento de percibir o financiamento. Depois, indentificou-se a atividade empreendedora na Argentina, e sua posição no ranking latinoamericano em decorrência do Índice de Condições Sistémicas para 0 Empreendimento Dinâmico que elabora o Programa de Desenvolvimento Empreendedor que se enquadra no Instituto de Indústria da Universidade Nacional de General Sarmiento (UNGS). Complementariamente, fez-se um relevo da estatística disponível de instrumentos financeiros aprovados destinados a Empreendedores. Dentro destes identificaram-se 198 instrumentos financeiros oferecidos pelos órgãos públicos nos diferentes estamentos da região Santa Fe, Córdoba e Buenos Aires, bem como organizações privadas nacionais e internacionais. 0 53,54\%
Palavras-chave

- Financiamento

- Empreendedor

- Empreendedorismo

- Instrumentos financieros

- Benefícios Promocionais 
dos instrumentos correspondem a prêmios, o 17,17\% são Aportes Não Reembolsáveis e 0 18,69\% são Créditos. Também realizaram-se entrevistas a informantes-chave (consultores, avaliadores, gerentes de entidades financeiras) com a finalidade de detectar os inconvenientes que afrontam os empreendedores para acessarem a fundos que os ajudam a desenvolverem seu empreendimento. 